\title{
Analysis of the Treatment of Synthetic Bathing Waters and Their Effects on Seedlings
}

\author{
Krisztina PÁL, ${ }^{1}$ Andrea IZBÉKINÉ SZABOLCSIK, ${ }^{2}$ Ildikó BODNÁR, ${ }^{3}$ Gábor BELLÉR ${ }^{4}$ \\ University of Debrecen, Faculty of Engineering, Department of Environmental Engineering, Hungary \\ ${ }^{1}$ palkrisztina23@gmail.com \\ ${ }^{2}$ szabolcsikandi@eng.unideb.hu \\ ${ }^{3}$ bodnari@eng.unideb.hu \\ ${ }^{4}$ bellér.gabor@eng.unideb.hu
}

\begin{abstract}
Synthetically produced bathing waters and their effect on seedlings were analysed in our research. The artificially produced bath waters were treated in different ways. Primarily, simple filtration was performed through a layer of silica sand. During the tests, the obtained greywater was investigated before and after the treatment with the help of various water quality parameters. Irrigation was set as the goal of recycling, and germination experiments were performed on mustard seeds. In these experiments, the synthetically generated treated and untreated bath water was used as irrigation water. Considering the results obtained during the germination, it can be said that the treatment is necessary in any case. Based on the results, it was shown that the filtration was not sufficient, so coagulation was used as an additional treatment method, for which we determined the optimal amount of treatment agent as a starting step.
\end{abstract}

Keywords: artificial bathwater, reuse, germination, treatment.

\section{Introduction}

Nowadays, the lack of fresh water is a growing global problem, as a result approx. one third of the population of the Earth do not have access to the recommended daily amount of drinking water. Based on sustainability goals, we must give priority to protect our available drinking water supplies. In places where there is already a shortage of drinking water, various treatment methods, e.g. drinking water produced from saline seawater by membrane technology, are applied, but these processes are particularly expensive solutions. A suitable method to prevent drinking water shortage could be e.g. the so called greywater treatment and reuse.

\section{About the greywater}

Domestic wastewater can be divided into two parts, black water which is that generated during toilet flushing, and greywater which is generated in water blocks and kitchens and does not contain faecal contaminants. Greywater can be generated during the washing of clothes, dishes and by bathing, too. Greywater generated during washing of dishes contains significant amounts of food residues, fats and dishwashing detergents. The greywaters from washing of clothes usually contains high concentrations of various chemicals. Based on our department's research and literature data, the least contaminated greywater fractions are the bathing or showering waters, which contain toiletries (shower gel, shampoo, soap) and additionally fats, oils and other impurities from the skin surface [1-3].

The daily water consumption per capita in Hungary is currently around 100-110 l. Approximately $38 \%$ of water consumption is used during bathing. Approximately 450 million $\mathrm{m}^{3}$ of wastewater enters sewage treatment plants annually. Significant savings can be achieved by treating and reusing $38 \%$ of this quantity, nearly 171 million $\mathrm{m}^{3}$ of less polluted wastewater.

Wastewater generated during bathing can be reused in number of ways after treatment. The 
two common uses are the toilet flushing and the irrigation [4, 5].

Based on the above features, we chose bathing waters as the fraction to be treated and recycled as the basis of our research, and we investigated, after various treatments, irrigation as a reuse opportunity, with the help of seedlings.

\section{Materials and methods}

The raw samples of our research were synthetic bathing water, created by a recipe developed by the research group of the Department of Environmental Engineering. The water quality parameters of the obtained synthetic bathing water samples represent well the properties of the bathing waters generated during everyday life. Bathing waters were created from two types of ingredients: traditional toiletries or so-called eco-cleaners as ingredients, dissolving these components in drinking water $[1,6,7]$

In the first experimental phase, the syntheticalyly created constant concentration bathing waters were treated by simple gravity filtration (Figure 1) using silica sand as a filtering layer [8].

In order to monitor the continuous treatment efficiency, we examined the synthetic bathing water in treated and untreated form, and we also analysed the drinking water that forms the basis of the bathing water. The following water qua-

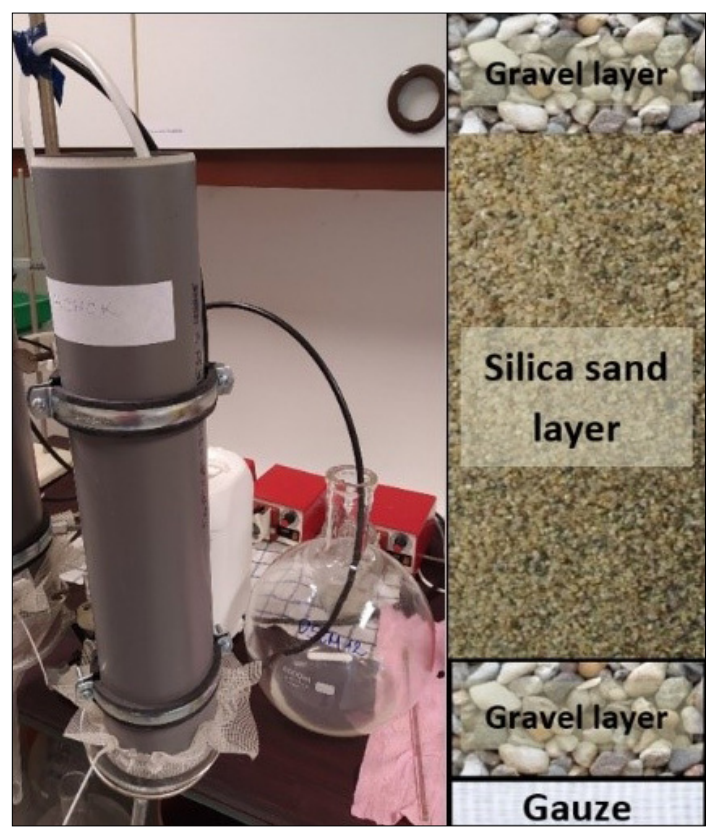

Figure 1. Silica sand filter media lity parameters were examined during the measurements: $\mathrm{pH}$, zeta potential, specific electrical conductivity, turbidity, biological oxygen demand $\left(\mathrm{BOD}_{5}\right)$, total organic carbon $(\mathrm{T} / \mathrm{DOC})$ and ANA detergent content of the samples. We used the following equipment and methods during the examinations: WTW SenTix 41-3 pH measuring electrode for the $\mathrm{pH}$ measurement, Zetasizer Nano Z device for the determination of zeta potential and specific electrical conductivity, OxiTop IS 12 manometric BOI measuring bottles for $\mathrm{BOI}_{5}$, and Shimadzu TOC- $\mathrm{V}_{\mathrm{CPN}}$ device for total organic carbon content measurement. The ISO 2271: 1989 standard was used to determine the ANA detergent content of the analysed samples [9, 10].

Irrigation was set as the goal of reuse, for this purpose germination experiments were performed on white mustard seeds. Untreated and treated synthetic bathing water was used as irrigation water, and irrigation with drinking water was also performed as a control study. The experiment was also carried out with bathing water contaminated with conventional and eco-toiletries, as well. Germination according to the standard was performed for 72 hours, followed by germ analysis [11]. The following characteristics were measured during the study: number of germinated seeds, root and stem length, moisture content, wet and dry biomass weight, as well as elemental analysis of germs (measured by Agilent ICP-OES instrument) [10].

During the treatment, we continuously monitored the change in water quality characteristics, from which it was concluded that the filtration applied in the first experimental phase was not sufficient. As a result, we applied chemical treatment involving coagulation experiments. As a first step, we determined the optimal amount of coagulant by measuring the zeta potential, ensuring the optimal amount of treatment agent for our subsequent complex treatments.

\section{Conclusions}

During our studies, we performed 2 series of measurement using bathing water samples containing conventional and eco-toiletries. The results obtained during the analysis of the samples are described in this section.

\subsection{Changes in water quality parameters as a result of treatment}

The average $\mathrm{pH}$ value of the untreated synthetic bathing water was $7.81 \pm 0.03$, while in the case of the ecosynthetic bathing water, it was $8.10 \pm 0.2$. 
Filtration on silica sand resulted in a minimal decrease in $\mathrm{pH}$; for the synthetic sample it changed to $7.61 \pm 0.04$, and the $\mathrm{pH}$ of the samples containing eco-cleaners changed to $7.73 \pm 0.05$.

During measuring the zeta potential, there was a minimal decrease in the synthetic sample's value due to filtration, the mean value changed from $(-12.4) \pm 2.3 \mathrm{mV}$ to $(-12.1) \pm 1.6 \mathrm{mV}$. However, a significant decrease was observed in the zeta potential of ecosynthetic samples. The mean value for the untreated sample was $(-31.4) \pm 0.4 \mathrm{mV}$ and after filtration, the zeta potential reached $(-15.6) \pm 1 \mathrm{mV}$.

As a result of the treatment, the specific electrical conductivity of the samples also decreased in both groups of samples. The synthetic sample's mean value was $897 \pm 0.03 \mu \mathrm{S} / \mathrm{cm}$ before the treatment, while the ecosynthetic bathing water showed $881 \pm 0.06 \mu \mathrm{S} / \mathrm{cm}$ value. Due to the filtration, these parameters decreased to $754 \pm 0.08 \mu \mathrm{S} / \mathrm{cm}$ in the former case and to $730 \pm 0.1 \mu \mathrm{S} / \mathrm{cm}$ in the latter case.

The total organic carbon content (T/DOC) of the two groups of samples was almost the same: the average TOC of the synthetic samples was $72 \pm 1 \mathrm{mg} / \mathrm{l}$, while that of the ecosynthetic samples was $70 \pm 4 \mathrm{mg} / \mathrm{l}$. Even after the treatment, the TOC values decreased to $17 \pm 1 \mathrm{mg} / \mathrm{l}$ for synthetic bathing waters and to $22 \pm 2 \mathrm{mg}$ for ecosynthetic bathing water samples.

In the case of wastewater entering the environment, it is important to measure the so-called ANA detergent content of the bathing water. Detergent-type pollutants in bathing water can have a significantly harmful effect on our environment and natural water source [12]. Measurements of the anionic detergent content (ANA value) showed that the detergent content of the ecosynthetic samples ( $51 \pm 1 \mathrm{mg} / \mathrm{l})$ was twice as large as that of the water sample containing conventional detergents $(22 \pm 1 \mathrm{mg} / \mathrm{l})$. After filtration, anionic detergent content was within acceptable levels.

The international literature provides a recommendation for the treatment and recycling of greywater for two water quality parameters. The first parameter is the biological oxygen demand $\left(\mathrm{BOI}_{5}\right)$, which represents well the biodegradable organic matter content of bathing water. According to the recommendation, the condition for reuse is a BOD value below $10 \mathrm{mg} / \mathrm{l}$. The BOD value of the synthetic samples before filtration was $120 \pm 28 \mathrm{mg} / \mathrm{l}$, then after filtration this value decreased to $60 \pm 1 \mathrm{mg} / \mathrm{l}$, while in the case of eco-synthetic bathing waters it decreased from
$154 \pm 19 \mathrm{mg} / \mathrm{l}$ to $75 \pm 16 \mathrm{mg} / \mathrm{l}$. We can declare that the samples required further treatment based on the above recommendation.

The other important water quality characteristic is turbidity. According to the regulations currently in use in the United States, the turbidity of water intended for reuse is max. 5 NTU, with an average value of 2 NTU [13]. In the case of untreated samples, we found that the turbidity of water samples containing traditional toiletries $(46.7 \pm 2.5 \mathrm{NTU})$ was almost three times higher than that of ecosynthetic water samples $(15.8 \pm 0,1 \mathrm{NTU})$. After treatment, the turbidity of the samples decreased to $2.5 \pm 1.1 \mathrm{NTU}$ and $2.7 \pm 0.6$, respectively, thus we managed to reduce the turbidity of the water samples below the expected maximum value, but the expected turbidity value of 2 NTU has not yet been achieved [7, 14].

\subsection{Germination experiments}

In our research, we set irrigation and germination experiments on white mustard seeds as the goal of reuse after treatment. Irrigation was also performed with untreated and treated synthetic bathing water samples and drinking water, respectively. For each type of irrigation water, 3-3 petri dishes were used, in which 25-25 mustard seeds of the same size and appearance were prepared (Figure 2). The duration of the standard experiment was 72 hours, watering was performed with $10 \mathrm{ml}$ of water per sample per day.

The germs grown from the seeds were examined, and based on the measurement data, it was determined that the bathing water must be treated before irrigation. The comparison was made against germs irrigated with drinking water.

Table 1. shows the length of the root sections and the percentage change in root length. Root lengths for control drinking water averaged $19 \pm 2 \mathrm{~mm}$ and $23 \pm 2 \mathrm{~mm}$. In the case of the synthetic water samples, the root length of the germs irrigated with untreated bathing water showed a $37.2 \%$ decrease compared to the control, whi-

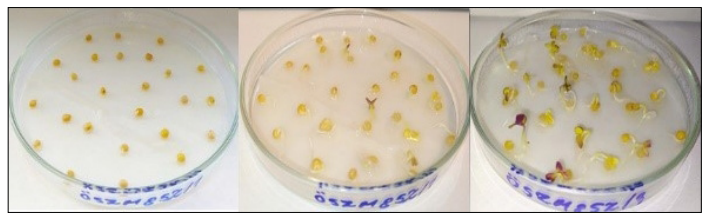

Figure 2. Development processes of white mustard seed germ. 
le that of the treated samples showed an overgrowth of $14.4 \%$.

Regarding the root length of the germs irrigated with ecosynthetic water samples, we found that, similar to the synthetic samples, irrigation with untreated bathing water showed a $35.5 \%$ decrease in the root length of the germs, while in the case of germs irrigated with treated samples, we observed $7.5 \%$ overgrowth compared to those irrigated with drinking water samples.

Based on Table 2 changes in stem length were analysed. The average stem lengths of the germs irrigated with control drinking water were $19.0 \pm 1.5 \mathrm{~mm}$ ad $23.3 \pm 1.4 \mathrm{~mm}$. Compared to these values, the stem lengths of germs irrigated with samples containing untreated conventional detergents showed a decrease of $33.5 \%$, while the stem lengths of germs irrigated with samples containing eco-detergents showed decrease of $42.3 \%$. The treated samples indicated overgrowth for both sample groups, $8.9 \%$, for irrigation with synthetic, and $2.4 \%$ with ecosynthetic samples.

In our further studies, we analysed the wet and dry biomass weight of the germ samples and the moisture content that can be determined from them. The following tables (Table 3 and 4) illustrate the moisture content of the root and stem parts.

In the case of the root part (Table 3), a significant difference can be observed in the case of irrigation with untreated samples. The difference of more than $10 \%$ can be explained by the phenomenon that the detergent content present in the untreated bathing water may have clogged the moisture-absorbing pores of the root part, so that these germs received less moisture.

The moisture contents of the stem parts (Table 4) showed almost similar results to the root parts, it can be assumed that in the case of these samples not enough moisture got from the root part to the stem part. The difference in this case is also close to $10 \%$.

Elemental analyses were also performed on the germs in order to monitor the effect of irrigation water on the micro- and macroelement content.

Among the microelements (Figure 3) significant amounts of iron, zinc and manganese were identified in the stem part, while boron, copper, iron and zinc were identifiable in the root parts.

Evaluating the macroelement concentrations (Figure 4) we observed that calcium, potassium and copper were mostly stored in the stem parts, while calcium, potassium and iron showed higher concentrations in the root parts.
Table 1. Data on the length of root parts

\begin{tabular}{|l|c|c|c|c|}
\hline \multirow{1}{*}{ ROOT } & $\begin{array}{c}\text { Synthetic } \\
\text { bathing } \\
\text { water }\end{array}$ & Change & $\begin{array}{c}\text { ECO } \\
\text { synthetic } \\
\text { bathing } \\
\text { water }\end{array}$ & Change \\
\cline { 2 - 5 } & $\begin{array}{c}\text { mm } \\
\text { Average } \\
\pm \text { SD }\end{array}$ & $\%$ & $\begin{array}{c}\text { mm } \\
\text { Average } \\
\mathbf{\text { SD }}\end{array}$ & $\%$ \\
\hline $\begin{array}{l}\text { Drinking } \\
\text { water }\end{array}$ & $19.45 \pm 2.36$ & - & $23.43 \pm 1.73$ & - \\
\hline $\begin{array}{l}\text { Untreated } \\
\text { water }\end{array}$ & $12.22 \pm 2.16$ & -37.17 & $15.12 \pm 1.36$ & -35.47 \\
\hline $\begin{array}{l}\text { Treated } \\
\text { water }\end{array}$ & $22.26 \pm 1.72$ & +14.42 & $25.18 \pm 0.59$ & +7.46 \\
\hline
\end{tabular}

Table 2. Data on the length of stem parts

\begin{tabular}{|l|c|c|c|c|}
\hline \multirow{1}{*}{ SZÁR } & $\begin{array}{c}\text { Synthetic } \\
\text { bathing } \\
\text { water }\end{array}$ & Change & $\begin{array}{c}\text { ECO } \\
\text { synthetic } \\
\text { bathing } \\
\text { water }\end{array}$ & Change \\
\cline { 2 - 5 } & $\begin{array}{c}\text { mm } \\
\text { Avera- } \\
\text { ge } \pm \text { SD }\end{array}$ & \% & $\begin{array}{c}\text { mm } \\
\text { Avera- } \\
\text { ge } \pm \text { SD }\end{array}$ & $\%$ \\
\hline $\begin{array}{l}\text { Drinking } \\
\text { water }\end{array}$ & $19.0 \pm 1.5$ & - & $23.3 \pm 1.4$ & - \\
\hline $\begin{array}{l}\text { Untrea- } \\
\text { ted water }\end{array}$ & $12.7 \pm 0.3$ & -33.5 & $13.5 \pm 0.1$ & -42.3 \\
\hline $\begin{array}{l}\text { Treated } \\
\text { water }\end{array}$ & $20.7 \pm 1.2$ & +8.9 & $23.9 \pm 1.6$ & +2.4 \\
\hline
\end{tabular}

Table 3. Moisture content of root parts

\begin{tabular}{|c|c|c|}
\hline \multirow{2}{*}{ ROOT } & $\begin{array}{c}\text { Synthetic bat- } \\
\text { hing water }\end{array}$ & $\begin{array}{c}\text { ECO synthetic } \\
\text { bathing water }\end{array}$ \\
\cline { 2 - 3 } & \multicolumn{2}{|c|}{ Moisture content } \\
\cline { 2 - 3 } & \multicolumn{2}{|c|}{$\%$ Average \pm SD } \\
\hline Drinking water & $94.54 \pm 0.29$ & $93.13 \pm 1.91$ \\
\hline Untreated water & $85.89 \pm 2.01$ & $85.46 \pm 0.96$ \\
\hline Treated water & $94.59 \pm 0.79$ & $93.81 \pm 1.33$ \\
\hline
\end{tabular}

Table 4. Moisture content of stem parts

\begin{tabular}{|c|c|c|}
\hline \multirow{2}{*}{ PLANT STEM } & $\begin{array}{c}\text { Synthetic bat- } \\
\text { hing water }\end{array}$ & $\begin{array}{c}\text { ECO synthetic } \\
\text { bathing water }\end{array}$ \\
\cline { 2 - 3 } & \multicolumn{2}{|c|}{ Moisture content } \\
\cline { 2 - 3 } & \multicolumn{2}{|c|}{$\%$ Average \pm SD } \\
\hline Drinking water & $76.6 \pm 0.7$ & $74.5 \pm 1.8$ \\
\hline Untreated water & $66.4 \pm 1.9$ & $63.7 \pm 1.6$ \\
\hline Treated water & $79.8 \pm 0.2$ & $75.6 \pm 3.1$ \\
\hline
\end{tabular}




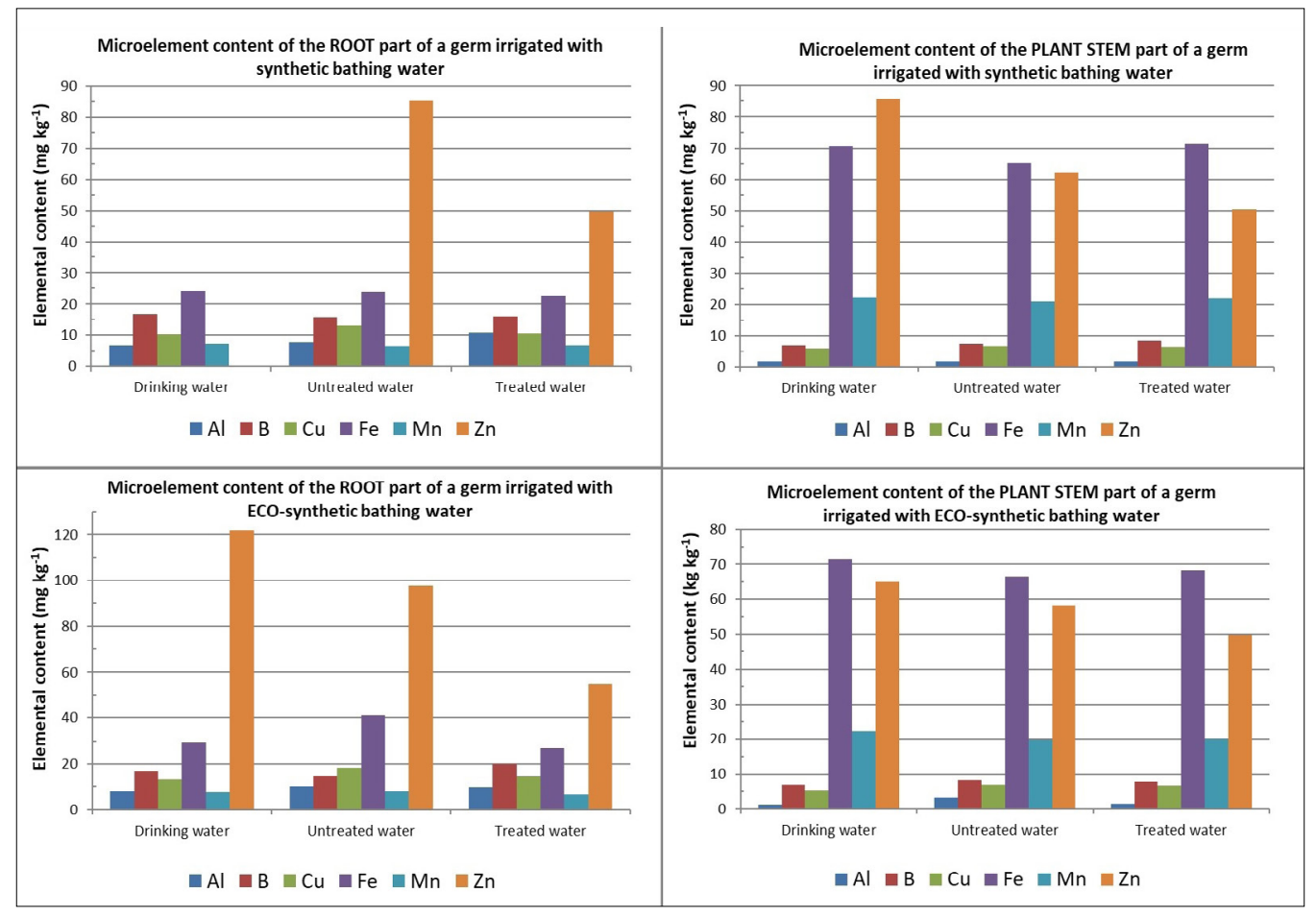

Figure 3. Content of microelements in each plant part.

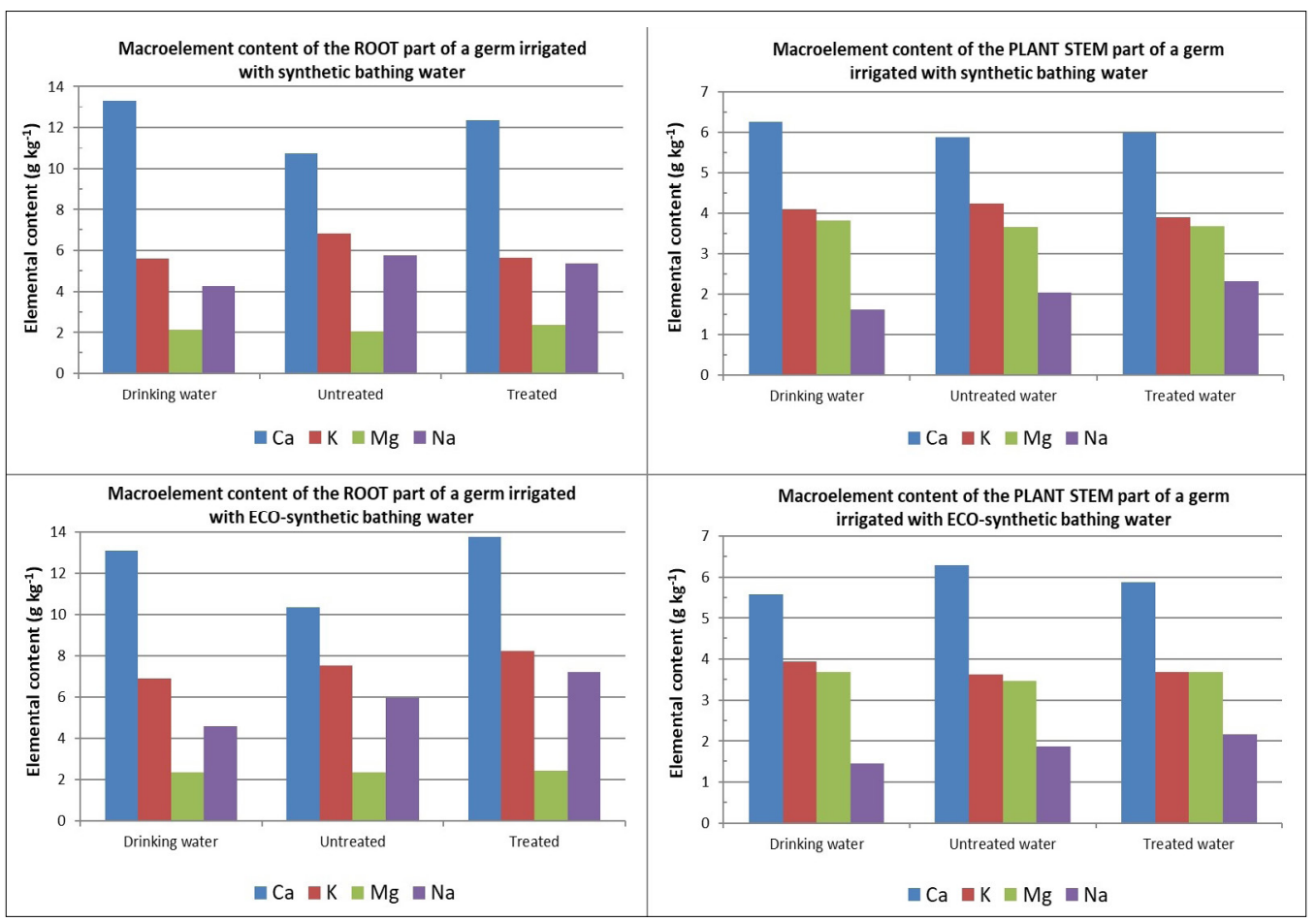

Figure 4. Content of macroelements in each plant part. 


\subsection{Coagulation}

At the beginning of our experiments, we treated the synthetically produced bathing water samples by simple silica sand filtration. The effectiveness of the treatment did not prove to be sufficient considering the international recommendations, so we planned to supplement the filtration operation with chemical treatment. Coagulation with iron(III)-chloride was chosen as a chemical treatment, with which the dissolved components in the samples can be converted into insoluble precipitates, settled and filtered out [15].

As an initial step, the optimal amount of coagulant required was determined by measuring the zeta potential. Coagulation can be considered successful if the value of the zeta potential of the treated samples is between $-5 \mathrm{mV}$ and $5 \mathrm{mV}$ or if the so-called $0 \mathrm{mV}$ zeta potential corresponds to an isoelectric point. A $25 \mathrm{~g} / \mathrm{l}$ concentration of iron(III)-chloride (prepared from $\left(\mathrm{FeCl}_{3} \times 6 \mathrm{H}_{2} \mathrm{O}\right.$ ) was used for the procedure. Coagulation experiments were performed to determine the optimal amount of coagulant. The results of the experiments are shown in Figure 5.

In the case of synthetic bathing water samples (Figure 6) the amount of optimal coagulant in the range $-5 \mathrm{mV}$ and $5 \mathrm{mV}$ kcan be given as a minimum concentration of $90 \mathrm{mg} / \mathrm{l}$ and a maximum concentration of $99 \mathrm{mg} / \mathrm{l}$.

For ecosynthetic bathing water samples (Figure 7) the addition of $94-107 \mathrm{mg} / \mathrm{F} \mathrm{Fe}^{3+}$ is required.

In our further research, based on the results described above, we plan to significantly improve the quality of the treated bathing water by sand filtration on $4 \mathrm{l}$ samples instead of $1 \mathrm{l}$ after our coagulation experiments. In this way, we are likely to meet the limit values of the parameters included in the international recommendations. Following the scaleup, it is planned to carry out experiments on new germination and possibly more advanced plants.

\section{Acknowledgments}

We would like to thank Dr. Edina Baranyai and Zsófia Sajtos for their help in examining the element content of the samples during our research.

The preparation of the publication and the presentation was supported by the project EFOP-3.6.116-2016-00022. The project was supported by the European Union and co-financed by the European Social Fund.

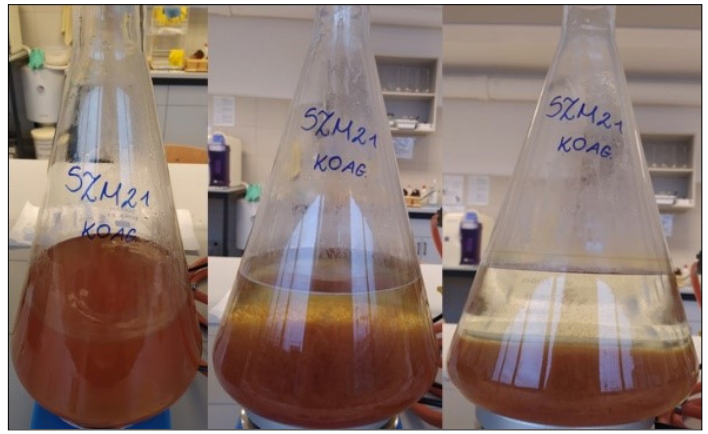

Figure 5. Coagulation process. The sample after the addition of the coagulant mixed during and after settled.

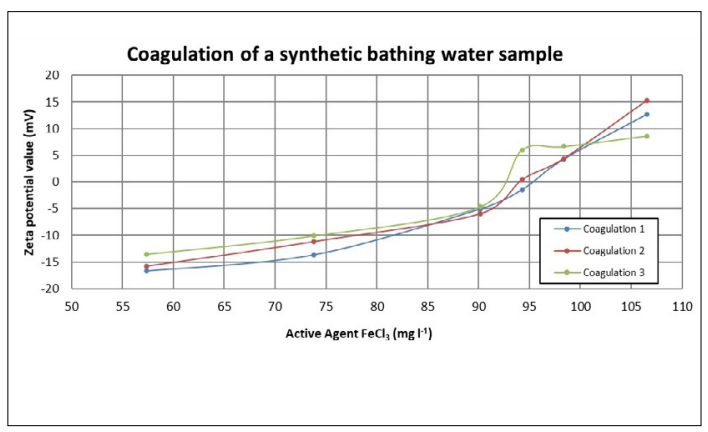

Figure 6. Coagulation of bathing water samples containing traditional toiletries.

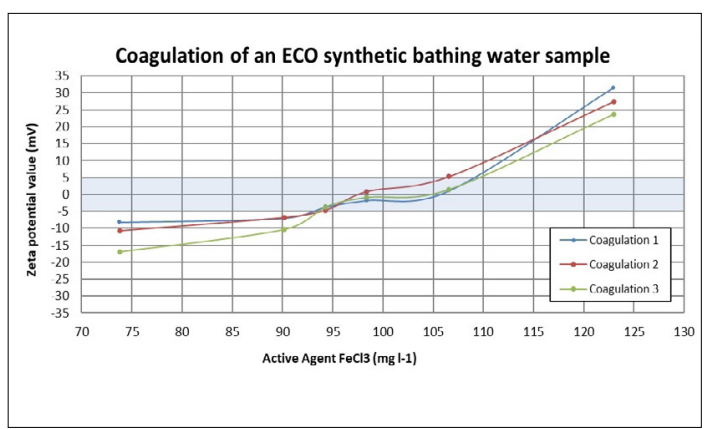

Figure 7. Coagulation of bathing water samples containing ECO toiletries.

\section{References}

[1] Bodnár I., Boros N., Fehérné Baranyai E., Fórián S., Izbékiné Szabolcsik A., Jolánkai G., Keczánné Üveges A., Kocsis D.: Épületek csapadékvizeinek és szürkevizeinek vizsgálata az Észak-Alföld régióban környezetbarát és energiahatékony hasznosítás céljából. In: Kalmár F. (szerk.): Fenntartható energetika megújuló energiaforrások optimalizált integrálásával. Akadémiai Kiadó, Budapest. 2014. 167-201. 
[2] Allen L., Christian-Smith J., Palaniappan M.: Overview of Greywater Reuse: the Potential of Greywater Systems to Aid Sustainable Water Management. Pacific Institute, 654/1. (2010) 19-21.

[3] Bilson S.: How Greywater Systems Work. ProQuest, 1998.

[4] Winward G. P., Avery L. M., Frazer-Williams R., Pidou,M., Jeffrey P., Stephenson T., Jefferson B.: A Study of the Microbial Quality of Grey Water and an Evaluation of Treatment Technologies for Reuse. Ecological Engineering, 32/2. (2008) 187-190.

[5] Barker-Reid F., Harper G. A., Hamilton A. J.: Affluent Effluent: Growing Vegetables with Wastewater in Melbourne, Australia-a Wealthy but BoneDry City. Irrigation and Drainage Systems, 24/1. (2010) 79-94.

[6] Bodnar I., Szabolcsik A., Baranyai E., Uveges A., Boros N.: Qualitative Characterization of the Household Greywater in Northern Great Plain Region of Hungary. Environmental Engineering and Management Journal, 13/11. (2014) 2717-2724. https://doi.org/10.30638/eemj.2014.302

[7] Szabolcsik A., Baranyai E. Bodnár I.: Utilization of Modern Analytical Techniques for the Analysis of House-Hold Generated Greywater Samples. International Review Of Applied Sciences And Engineering, 6/1. (2015) 53-59.

[8] Dubey A. K., Sahu O.: Review on Natural Methods for Waste Water Treatment. Journal of Urban and Environmental Engineering, 8/1. (2014) 89-97. https://www.redalyc.org/articulo.oa?id=2832324 12009
[9] Ghaitidak D. M., Yadav K. D.: Characteristics and Treatment of Greywater - a Review. Environmental Science and Pollution Research, 20/5. (2013) 2795-2809.

https://doi.org/10.1007/s11356-013-1533-0

[10] Finley S., Barrington S., Lyew D.: Reuse of Domestic Greywater for the Irrigation of Food Crops. Water, Air, and Soil Pollution, 199/1. (2009) 235-245. https://doi.org/10.1007/s11270-008-9874-x

[11] MSZ 22902-4: Víztoxikológiai vizsgálatok, 1990.

[12] Bhairi S. M., Mohan C.: Detergents: A Guide to the Properties and Uses of Detergents in Biology and Biochemistry. EMD Biosciences, SanDiego, CA, 2007.

[13] USEPA (United States Environmental Protection Agency), Guidelines for Water Reuse. Report EPA/625/R-04/108, USEPA, Washington, DC, USA. 2004.

[14] Oron G., Adel M., Agmon V., Friedler E., Halperin R., Leshem E., Weinberg D.: Greywater Use in Israel and Worldwide: Standards and Prospects. Water Research, 58, (2014) 92-101. https://doi.org/10.1016/j.watres.2014.03.032

[15] Ghaitidak D. M., Yadav K. D.: Reuse of Greywater: Effect of Coagulant. Desalination and Water Treatment, 54/9. (2015) 913-925. https://doi.org/10.1080/19443994.2014.924036 